\title{
BURNOUT AND DEMOGRAPHIC CHARACTERISTICS OF WORKERS EXPERIENCING DIFFERENT TYPES OF WORK-HOME INTERACTION
}

\author{
DOROTA MERECZ and ALEKSANDRA ANDYSZ
}

Nofer Institute of Occupational Medicine, Łódź, Poland

Department of Occupational Psychology

\begin{abstract}
Objectives: The purpose of this study was to explore configurations of positive versus negative interactions between work and home (WHI) and their relation to burnout and demographic characteristics. Material and Methods: Sample of 533 Polish workers were interviewed by means of self-administered questionnaires (SWING and MBI-GS). Demographic and work characteristics were also controlled. Results: Cluster analysis distinguished 5 types of WHIs: positive WHI (18\%), negative WHI (15.9\%), no interaction (29.3\%), mutual positive interactions $(15.4 \%)$ and positive HWI $(21.4 \%)$. The quality of WHI was associated with number of work hours and tenure at main place of employment. The effect of gender on the quality of work-home interaction was not significant. Configuration of WHIs affected the level of burnout. Again, there was no significant difference between men and women in terms of burnout and its sub-dimensions. The least burned-out were people from positive WHI, positive HWI and mutual positive interaction groups. The most burned-out were people who experienced negative WHI the most often. In this group, predominance of men working more than $10 \mathrm{~h}$ per day was observed. The majority of study group (71\%) experienced rather integration than segmentation of both spheres. Conclusions: Our results suggest that segmentation is not an universal and effective strategy of coping with work and home demands - it may prevent the positive home-work spillover, which can be buffer or remedy against stress or burnout. We consider cluster analysis the appropriate method in research on relation to work-family balance issue, which may be useful in unraveling relationships between this phenomenon and attitudes and behaviors.
\end{abstract}

Key words:

Burnout, Work-home interaction, Work-life balance, Cluster analysis

\section{INTRODUCTION}

Many researches investigate factors that affect quality of life and occupational activity. Among others, such phenomena as job burnout and interaction between work and private life domains are in scope of scientific interest.

\section{Work-family issue}

Research on relationships between work and life domains is characterized by a diversity of theoretical approaches. Researchers distinguish a variety of mechanisms linking work and family: spillover, compensation, segmentation, resource drain, congruence or conflict [1]. Taking the number of publications into account, it becomes obvious that this area of research is dominated by searching for antecedents and consequences of work-life conflict. Conflicting demands of work and private life as well as burnout are responsible for poorer well-being, dissatisfaction, somatic complaints, fatigue and problems in everyday functioning. Well-balanced relationship between work and private life and healthy engagement, which is the opposite of burnout,

Received: April 24, 2014. Accepted: July 1, 2014.

Corresponding author: A. Andysz, Nofer Institute of Occupational Medicine, Department of Occupational Psychology, św. Teresy 8, 91-348 Łódź, Poland (e-mail: andysz@imp.lodz.pl). 
help people to gain sense of fulfillment, happiness and to stay productive and healthy for longer. On the one hand, performing multiple roles can cause overload, strains and conflicts because the responsibilities from the different domains compete for limited reservoir of resources. On the other hand, this interaction can be also beneficial because positive moods and emotions, values, skills, competences, experiences and behaviors acquired in one domain can be transferred to the other, and such a positive spillover improves the ability of meeting demands of the role in the other domain. Such an approach is promoted by Geurts et al. [2] who suggest that activity in private and occupational life requires effort and produces specific reactions to the load. Reactions to the load in the form of mood, emotions and behaviors can be positive or negative depending on the ratio of effort to possibilities of regeneration. Moreover, these states and behaviors can be transferred form one sphere to another. On the basis of this assumption, work-home interaction (WHI) was defined as "a process in which a worker's functioning (behavior) in one domain (e.g., home) is influenced by (negative or positive) load reactions that have built up in the other domain (e.g., work)" [2, p. 322].

\section{Burnout}

Burnout is one of the most often studied outcomes of work-life conflict or imbalance [3-5]. It is considered as a phenomenon that affects more and more employees and has one of the most important effects on psychosocial wellbeing [6-8]. The most popular theory of burnout is the one developed by Maslach and her colleagues. Burnout may be defined as a "syndrome of emotional exhaustion, depersonalization, and reduced personal accomplishment that can occur among individuals who do 'people work' of some kind" [9], or a set of negative outcomes of prolonged work stress [7]. Already in the late 80's of the 20th century, some researches and practicians argued that job burnout was not only "the illness" of human services, but also it could become a problem to an employee of any occupation.

\section{Interaction of work-home and burnout in previous research}

Until recently, research on relationship between workhome interaction and burnout has mostly focused on medical professions [3,10-12]. Nowadays, along with the popularization of the concept of burnout, which is applicable not only to human services, we can observe an increasing interest in other occupational groups as bank clerks, insurance company employees, technical and administrative staff [13], construction professionals [4], or newspapers managers [14]. Possible relationships between work-life interaction and burnout were explained basing on: Conservation of Resources Theory [15]; Demand-ControlSupport Model of work stress [16]; or Job Demands-Resources Model [17].

All of the aforementioned theories underline the role of insufficient resources and/or excessive work demands in the development of negative work-home interaction and burnout. On the other hand, from perspective of Role Enhancement Theory, holding multiple roles may be beneficial for individual's well-being [18]. Thus it is reasonable to assume that there are such combinations of workhome interaction which may prevent individuals from being burnt out by job at least to some extent. Although works on that issue are rather sparse, one can find some promising evidences which support that assumption. For example Grzywacz [19] and Grzywacz and Bass [20] found that positive WHI and HWI was related with better health status and wellbeing.

For a long time researchers have been debating where WHI construct should be embedded in theoretical models [21]. In most studies, it was assumed that work-home conflict is a source of burnout $[4,10,22]$. Some research proved that burnout mediated relationship between stress and work-life conflict. Other authors 
showed that work-home interaction mediated the relationship between various variables (stress role, job/home demands and resources, workload, job schedule, organizational justice) [23], and burnout [4,14,21,24,25]. A few longitudinal studies brought the answer on the causal relationship between these phenomena [26-28]. One of the most frequently cited research shows that work pressure, WHI and emotional exhaustion cannot be definitely considered as only the cause or only a consequence, but they predict each other over time. This relationship was described as "loss spiral" [29].

\section{AIM OF THE RESEARCH}

The purpose of this study was, 1stly, to explore a possible configuration of positive versus negative interaction between work and home domains in the representative sample of Polish employees and 2ndly, to estimate their relation to burnout. We hypothesize that:

- H1 - there are different configurations of positive and negative work-home/home-work interaction.

We were also interested in socio-demographic specificity of extracted constellations of work-home interactions. We employed the approach proposed by Geurts et al. [2] that includes 2-fold nature of the relationship between private and work life and accounts its positive and negative aspects. We found that approach innovative because in previous research positive measures of work-home/ home-work interaction were rarely studied. The research of Montgomery et al. [14] is an exception. Also the impact of positive aspects of work-home interaction on burnout in previous research was often omitted.

According to the studies demonstrating the direct and indirect relations between work-home interaction (especially the conflict) and burnout [4,10], we consider the quality of work-home interaction as a resource buffering or catalyzing the experience of burnout $[14,30]$ and we formulated our next hypothesis:
- H2 - specific configurations of both positive and negative work-home/home-work interactions affect the level of experienced burnout.

In the study of Montgomery et al. [30], it has been shown that the work-home interaction mediates the relationship between requirements and resources of work and personal life and the experience of burnout. Work-home conflict was claimed to be one of the critical contributors of burnout what was proven earlier in research on surgeons [10]. We assumed that:

- H3 - people who experience the positive work-home/ home-work interaction most often, have significantly lower indices of emotional exhaustion and cynicism than others.

- H4 - people who experience the positive work-home/ home-work interaction most often, have significantly higher index of professional efficacy than others.

In recent years, gender differences in experiencing workhome interaction and burnout have been frequently studied [3,10,31-34]. Some authors reported that balancing work and family duties poses a greater challenge for women than for men [3,10,31,34]. Mostly, it is due to the double burden of women with domestic and work responsibilities. In a qualitative research by Emslie and Hunt [32], they found that presence of adolescent children caused lack of balance for both parents, but for women this difficulty lasted much longer. Taking situation of Polish workers: dual earners model of family and insufficient institutional facilities of child care into account, we have assumed that: - H5 -women from our sample will experience less positive work-home/home-work interaction than men.

It has been found that certain work variables e.g., work time schedule, self-employment, number and age of children, type of employment contract, are the factors that affect the relationship between work and private life [35-37]. Additionally, research of Dyrbye et al. [10] showed that such factors as: hours worked per week; occurrence of work-home conflict in the past 3 weeks; and resolving 
the most recent conflict in favor of work, contributed to burnout. Therefore, we have hypothesized that:

- H6 - working more hours per day is related to negative work-home/home-work interaction and burnout.

- H7 - self-employment is related to negative workhome/home-work interaction and burnout.

- H8 - shift work is related to negative work-home/homework interaction and burnout.

\section{MATERIAL AND METHODS}

\section{Measures}

\section{Work-home interaction}

We used a Polish version of Survey Work-Home Interaction - Nijmegen (SWING) by Geurts et al. [2,38] to measure the work-home interaction. The Polish version consists of 22 statements distinguished into 4 scales measuring independent dimensions:

- work positively influencing home (WHI+) (You are better able to keep appointments at home because your job requires this as well);

- work negatively influencing home (WHI-) (You are irritable at home because your work is demanding);

- home positively influencing work (HWI+) (After spending a pleasant weekend with your spouse/family/ friends, you have more fun in jour job);

- home negatively influencing work (HWI-) (You have difficulty concentrating on your work because you are preoccupied with domestic matters).

Respondents answered the questions using a 4-point scale 'never,' 'sometimes,' 'often' and 'always,' which were encoded as $-2,-1,1$, and 2, respectively. Psychometric properties of the Polish version of SWING questionnaire are satisfactory and comparable to the English one. The Cronbach's $\alpha$ of scales are as follows: for WHI+ $=0.73$; WHI- $=0.89$; WHI+ $=0.74$ and HWI- $=0.80$ [38]. In our study: 0.72, 0.89, 0.72 and 0.79 , respectively.
Burnout

A Polish version of Maslach Burnout Inventory - General Survey (MBI-GS) [39] was used to assess burnout. It measures burnout among professionals who do not have a contact with a customer or a client in their main duties. It consists of 3 scales: Emotional Exhaustion (5 items), Cynicism (5 items) and Professional Efficacy (6 items). Items are rated on 7-point Likert scale ranging from ' 0 ' (never) to '6' (every day). This adaptation of MBI-GS is characterized by content validity and high level of internal consistency. Three-factorial structure of the Polish MBI-GS was confirmed [40]. The Cronbach's $\alpha$ are as follows: for Emotional Exhaustion 0.81, Cynicism 0.73 and Professional Efficacy 0.79 [40]. In our study: 0.84, 0.79 and 0.86 respectively.

\section{Demographic variables}

We asked our respondents about their family situation, average number of employers working time, type of employment contract, work schedule and income. We also asked about respondents' age, overall tenure and tenure at the main place of employment.

\section{Methods of analysis}

The study was cross-sectional. To identify the possible configurations of WHI, we used a hierarchical cluster analysis using Ward's method of Euclidean distances and k-means clustering. This method let us get a wider picture of the work-life interaction issue. Considering different kinds of work-home interactions separately is a far-reaching simplification, because it is impossible to experience only a negative or only a positive spillover. Therefore, various types of work-home interaction should not be analyzed separately, because in reality, they are experienced simultaneously [26]. Such an understanding of work-home interaction seems the most appropriate to us. We should reflect on how the various dimensions interact with each other and how the 
configurations of these interactions influence other phenomena.

We suggest rather focus on the frequency of experiencing positive and negative interaction between home and work, and the ratio between them, because these indices constitute overall quality of work-home interaction. In fact, in many research, sub-scales of WHI questionnaires are interpreted separately, which leads to the scattered picture of the phenomenon. Cluster analysis is a way to avoid it - all sub-dimensions constitute a general index that can be called the general quality of relationship between work and private life.

In our theoretical model, the quality of work-home interaction differentiated groups of subjects and served as an independent variable while burnout was the dependent one. To compare the between-groups differences in burnout, we chose ranks comparison with Kruskal-Wallis test and post-hoc Dunn test.

With respect to gender, family situation, average work time, type of employment contract and income, $\mathrm{Chi}^{2}$ test was used. With respect to respondents' age, overall job tenure and tenure at the main place of employment, we investigated the differences between clusters using Kruskal-Wallis and Dunn tests. All calculations were made with the help of statistical packages SPSS v. 19, Statistica v. 10 and a free-licensed post-hoc Dunn test analysis software v. 7.01 [41].

\section{Participants}

The random sample of 533 Polish citizens of working age - representing various occupations - were recruited into the study. There were several exclusion criteria in the sampling procedure e.g., being on parental leave, receiving disability payment and being a full-time student or a pensioner. The participants were surveyed at home by means of a standardized questionnaires. The participation in the study was voluntary and non-profit. Women accounted for $50.3 \%$ of the group, men $-49.7 \%$.
In the whole sample the mean age was $39.2(\mathrm{SD}=11.2)$, average overall tenure was $17.2(\mathrm{SD}=11.4)$ and the average tenure at main place of employment was 9.5 $(\mathrm{SD}=9.4)$. The descriptive statistics and percentage distribution of the variables for groups are shown in Table 2 and 3 .

\section{RESULTS}

\section{Clusters identification}

Cluster analysis was executed for 3, 4 and 5 solutions. The results were most diversified and readily interpretable for 5 clusters (Figure 1). The type of interaction which was experienced most often (mean score above zero) served as the criterion for the interpretation of the results and the basis for labeling the clusters. Mean scores of SWING scales in clusters obtained using k-means method are shown in Table 1.

We highlighted:

- cluster 1 with respondents who experienced mainly positive influence of home to work - further referred as HWI+ group (21.4\% of the respondents);

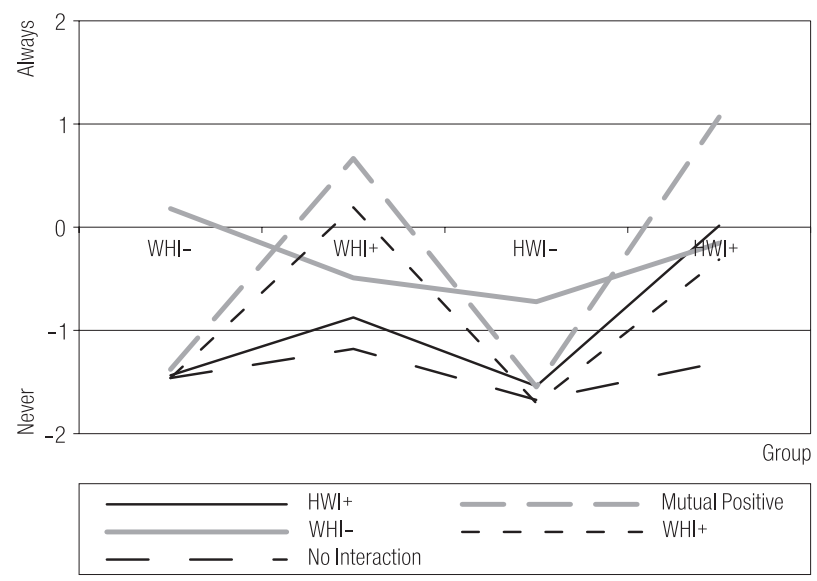

"HWI+" - home positively influencing work; "WHI-" - work negatively influencing home; "WHI+" - work positively influencing home; "HWI-" - home negatively influencing work.

Fig. 1. Mean scores of Survey Work-Home Interaction Nijmegen (SWING) questionnaire scales in clusters 
Table 1. Scores in 4 dimensions of Survey Work-Home Interaction - Nijmegen (SWING) questionnaire in study groups

\begin{tabular}{lcccc}
\hline \multirow{2}{*}{ Group } & \multicolumn{3}{c}{$\begin{array}{c}\text { SWING dimensions } \\
(\mathrm{M})\end{array}$} \\
\cline { 2 - 5 } & WHI- & WHI+ & HWI- & HWI+ \\
\cline { 2 - 5 } HWI+ group & -1.44 & -0.87 & -1.54 & 0.01 \\
WHI- group & 0.18 & -0.49 & -0.72 & -0.15 \\
No Interaction group & -1.46 & -1.18 & -1.67 & -1.31 \\
Mutual Positive group & -1.38 & 0.67 & -1.55 & 1.07 \\
WHI+ group & -1.46 & 0.19 & -1.71 & -0.31 \\
\hline
\end{tabular}

$\mathrm{M}$ - mean. Other abbreviations as in Figure 1.

- cluster 2 with respondents who experienced mainly negative interaction between work and home - WHIgroup (15.9\%);

- cluster 3 with respondents who did not experience any interaction - No Interaction group (29.3\%);

- cluster 4 with respondents who most often experienced mutual positive interactions between their work and home - Mutual Positive group (15.4\%);

- cluster 5 with respondents who, among other interactions, experienced positive interaction between work and home most often - WHI+ group (18\%).
The result indicates that mutual positive interactions and negative home to work interaction in our sample were experienced the least frequently. The characteristics of all clusters in terms of the controlled variables is summarized in Table 2 and 3.

\section{Differences in clusters for burnout}

The Kruskal-Wallis test results showed significant differences between groups in all 3 dimensions of burnout. Multiple post-hoc comparisons with Dunn test showed the differences between pairs (see Table 4).

Table 2. Descriptive statistic of the measured variables in study groups

\begin{tabular}{lccccc}
\hline \multicolumn{1}{c}{ Variable } & \multicolumn{5}{c}{$\begin{array}{c}\text { Group } \\
(\mathrm{M} \pm \mathrm{SD})\end{array}$} \\
\cline { 2 - 6 } & HWI & WHI- & No Interaction & $\begin{array}{c}\text { Mutual } \\
\text { Positive }\end{array}$ & WHI+ \\
\hline Age & $38.2 \pm 11.0$ & $37.7 \pm 10.1$ & $39.2 \pm 11.5$ & $41.7 \pm 11.3$ & $40.0 \pm 11.5$ \\
Overall tenure & $16.5 \pm 10.8$ & $14.9 \pm 10.6$ & $17.3 \pm 11.3$ & $19.6 \pm 12.1$ & $18.0 \pm 12.2$ \\
Tenure at main place of employment & $9.5 \pm 9.1$ & $7.0 \pm 7.8$ & $8.8 \pm 8.3$ & $12.0 \pm 11.0$ & $10.7 \pm 10.9$ \\
Overall burnout & $1.6 \pm 0.9$ & $2.3 \pm 0.8$ & $1.7 \pm 0.9$ & $1.1 \pm 0.7$ & $1.2 \pm 0.7$ \\
Exhaustion & $1.8 \pm 1.1$ & $3.0 \pm 1.2$ & $1.9 \pm 1.2$ & $1.4 \pm 1.0$ & $1.4 \pm 1.0$ \\
Cynicism & $1.6 \pm 1.1$ & $2.3 \pm 1.3$ & $1.6 \pm 1.1$ & $1.0 \pm 0.9$ & $1.1 \pm 0.9$ \\
Professional Efficacy & $4.6 \pm 1.0$ & $4.2 \pm 1.0$ & $4.4 \pm 1.1$ & $4.9 \pm 0.9$ & $4.9 \pm 0.8$ \\
\hline
\end{tabular}

SD - standard deviation. Other abbreviations as in Figure 1 and Table 1. 
Table 3. Demographic variables and significance of difference between them in study groups

\begin{tabular}{|c|c|c|c|c|c|c|}
\hline \multirow{2}{*}{ Variable } & \multicolumn{5}{|c|}{$\begin{array}{l}\text { Group } \\
(\%)\end{array}$} & \multirow{2}{*}{$\begin{array}{c}\mathrm{Chi}^{2} \\
\mathrm{p}\end{array}$} \\
\hline & HWI+ & WHI- & $\begin{array}{c}\text { No } \\
\text { Interaction }\end{array}$ & $\begin{array}{l}\text { Mutual } \\
\text { Positive }\end{array}$ & WHI+ & \\
\hline \multicolumn{7}{|l|}{ Gender } \\
\hline women & 45.6 & 43.5 & 55.1 & 53.7 & 47.9 & \multirow{2}{*}{$\begin{array}{l}\operatorname{Chi}^{2}(4,533)=4.531 \\
\quad p=0.339\end{array}$} \\
\hline men & 54.4 & 56.5 & 44.9 & 46.3 & 52.1 & \\
\hline \multicolumn{7}{|l|}{ Family situation } \\
\hline people living alone & 16.7 & 14.1 & 17.3 & 12.2 & 13.5 & \multirow{4}{*}{$\begin{array}{c}\operatorname{Chi}^{2}(12,533)=11.722 \\
p=0.468\end{array}$} \\
\hline $\begin{array}{l}\text { people in relationship with } \\
\text { dependents }\end{array}$ & 32.5 & 43.5 & 31.4 & 45.1 & 41.7 & \\
\hline $\begin{array}{l}\text { people in relationship without } \\
\text { children or dependents }\end{array}$ & 40.4 & 35.3 & 41.7 & 35.4 & 41.7 & \\
\hline people living with parents & 10.5 & 7.1 & 9.6 & 7.3 & 3.1 & \\
\hline \multicolumn{7}{|l|}{ Work hours per day } \\
\hline$\leq 8$ & 71.1 & 47.1 & 74.4 & 68.3 & 77.1 & \multirow{3}{*}{$\begin{array}{c}\operatorname{Chi}^{2}(8,533)=39.747 \\
\mathrm{p}<0.000\end{array}$} \\
\hline$\leq 10$ & 21.1 & 30.6 & 18.6 & 26.8 & 21.9 & \\
\hline$>10$ & 7.9 & 22.4 & 7.1 & 4.9 & 1.0 & \\
\hline \multicolumn{7}{|l|}{ Shift work } \\
\hline no & 59.6 & 54.1 & 65.4 & 69.5 & 65.6 & \multirow{2}{*}{$\begin{array}{c}\operatorname{Chi}^{2}(4,533)=5.584 \\
p=0.232\end{array}$} \\
\hline yes & 40.4 & 45.9 & 34.6 & 30.5 & 34.4 & \\
\hline \multicolumn{7}{|l|}{ Employers (n) } \\
\hline 1 & 96.5 & 90.6 & 94.9 & 89.0 & 92.7 & \multirow{2}{*}{$\begin{array}{c}\operatorname{Chi}^{2}(4,533)=5.879 \\
p=0.208\end{array}$} \\
\hline $\begin{array}{l}\text { at least } 1 \text { or/and self-employment/ } \\
\text { casual job }\end{array}$ & 3.5 & 9.4 & 5.1 & 11.0 & 7.3 & \\
\hline \multicolumn{7}{|l|}{ Income } \\
\hline not sufficient for basic needs & 4.4 & 4.7 & 6.5 & 6.1 & 3.1 & \multirow{5}{*}{$\begin{array}{c}\operatorname{Chi}^{2}(4,533)=14.465 \\
p=0.564\end{array}$} \\
\hline sufficient only for basic needs & 35.1 & 27.1 & 36.8 & 28.0 & 21.9 & \\
\hline $\begin{array}{l}\text { sufficient for meeting current needs } \\
\text { without having to worry whether it } \\
\text { will be enough until the end of the } \\
\text { month }\end{array}$ & 43.0 & 44.7 & 40.0 & 46.3 & 49.0 & \\
\hline $\begin{array}{l}\text { allowing for savings on unplanned } \\
\text { expenses in the future }\end{array}$ & 15.8 & 16.5 & 13.5 & 14.6 & 19.8 & \\
\hline $\begin{array}{l}\text { high enough that I can live without } \\
\text { major sacrifices and put off for the } \\
\text { future }\end{array}$ & 1.8 & 7.1 & 3.2 & 4.9 & 6.3 & \\
\hline
\end{tabular}

Abbreviations as in Figure 1. 
Table 4. Significance of differences in burnout between clusters (Dunn and Kruskal-Wallis tests results) in study groups

\begin{tabular}{|c|c|c|c|c|c|c|}
\hline \multirow[b]{2}{*}{ Variable } & \multicolumn{5}{|c|}{ Dunn test } & \multirow[b]{2}{*}{ Kruskal-Wallis test } \\
\hline & $\begin{array}{c}\text { HWI+ } \\
\text { group }\end{array}$ & $\begin{array}{l}\text { WHI- } \\
\text { group }\end{array}$ & $\begin{array}{c}\text { No } \\
\text { Interaction } \\
\text { group }\end{array}$ & $\begin{array}{l}\text { Mutual } \\
\text { Positive } \\
\text { group }\end{array}$ & $\begin{array}{l}\text { WHI+ } \\
\text { group }\end{array}$ & \\
\hline Emotional Exhaustion & & & & & & $\mathrm{H}(4,533)=87.387^{* * *}$ \\
\hline HWI+ group & - & $-6.089^{*}$ & -0.690 & 2.703 & 2.338 & \\
\hline WHI- group & $6.089^{*}$ & - & $5.841^{*}$ & $8.166^{*}$ & $8.033^{*}$ & \\
\hline No Interaction group & 0.690 & $-5.841^{*}$ & - & $3.493^{*}$ & $3.153^{*}$ & \\
\hline Mutual Positive group & -2.703 & $-8.166^{*}$ & $-3.493^{*}$ & - & -0.449 & \\
\hline WHI+ group & -2.338 & $-8.033^{*}$ & $-3.153^{*}$ & 0.449 & - & \\
\hline Cynicism & & & & & & $\mathrm{H}(4,533)=67.771^{* * *}$ \\
\hline HWI+ group & - & $-3.846^{*}$ & 0.150 & $3.926^{*}$ & $3.238^{*}$ & \\
\hline WHI- group & $3.846^{*}$ & - & $4.226^{*}$ & $7.234^{*}$ & $6.713^{*}$ & \\
\hline No Interaction group & -0.150 & $-4.226^{*}$ & - & $4.032^{*}$ & $3.315^{*}$ & \\
\hline Mutual Positive group & $-3.926^{*}$ & $-7.234^{*}$ & $-4.032 *$ & - & -0.798 & \\
\hline WHI+ group & $-3.238^{*}$ & $-6.713^{*}$ & $-3.315^{*}$ & 0.798 & - & \\
\hline Professional Efficacy & & & & & & $\mathrm{H}(4,533)=37.991^{* * *}$ \\
\hline HWI+ group & - & 2.423 & 1.017 & -2.721 & -2.668 & \\
\hline WHI- group & -2.423 & - & -1.646 & $-4.788^{*}$ & $-4.813^{*}$ & \\
\hline No Interaction group & -1.017 & 1.646 & - & $-3.807^{*}$ & $-3.815^{*}$ & \\
\hline Mutual Positive group & 2.721 & $4.788^{*}$ & $3.807^{*}$ & - & 0.162 & \\
\hline WHI+ group & 2.668 & $4.813^{*}$ & $3.815^{*}$ & -0.162 & - & \\
\hline Overall Burnout & & & & & & $\mathrm{H}(4,533)=99.885^{* * *}$ \\
\hline HWI+ group & - & $-5.457^{*}$ & -0.832 & $3.762^{*}$ & $3.460^{*}$ & \\
\hline WHI- group & $5.457^{*}$ & - & $5.040^{*}$ & $8.572^{*}$ & $8.469^{*}$ & \\
\hline No Interaction group & 0.832 & $-5.040^{*}$ & - & $4.746^{*}$ & $4.485^{*}$ & \\
\hline Mutual Positive group & $-3.762 *$ & $-8.572^{*}$ & $-4.746^{*}$ & - & -0.436 & \\
\hline WHI+ group & $-3.460^{*}$ & $-8.469^{*}$ & $-4.485^{*}$ & 0.436 & - & \\
\hline
\end{tabular}

*** $\mathrm{p}<0.001 ; * \mathrm{p}<0.05$.

Abbreviations as in Figure 1.

Emotional Exhaustion was significantly the highest in the WHI- group. The level of Emotional Exhaustion was also elevated, but moderate compared to other clusters, in No Interaction group. There were no significant differences between HWI+, Mutual Positive and WHI+. These groups had the lowest scores in this scale. The WHIgroup obtained the significantly highest scores on Cynicism subscale. The Cynicism scores of the HWI+ group were significantly higher than the ones of Mutual Positive and WHI+ groups. No Interaction group differed significantly from HWI+, but the level of Cynicism was significantly higher there than in Mutual Positive and WHI+ groups.

In terms of Cynicism, gradation looks like this: the strongest in WHI- group, then in groups: HWI+ and No Interaction, and the smallest in Mutual Positive 
and WHI+ groups. When taking the Professional Efficacy into account, the comparison between groups showed the smallest variation of the results. The highest scores were obtained in groups WHI+, HWI+ and Mutual Positive and the lowest in WHI- and No Interaction groups.

Between-clusters comparison of overall score in MBI-GS shows that WHI- group had the highest index of Burnout. In the HWI+, Mutual Positive and WHI+ groups the score was the lowest. No Interaction group was characterized by an average level of Burnout.

When we compared ranks in MBI-GS subscales and overall score for women and men, for both groups no significant differences occurred (analysis not shown).

\section{Differences in clusters}

\section{as regards demographic variables}

Kruskal-Wallis test showed significant differences between clusters only in relation to tenure at the main place of employment (Table 5). The Dunn test showed a significant difference only between 2 groups: WHI- and Mutual Positive. People from the latter group worked longer at the current position.

The $\mathrm{Chi}^{2}$ test of independence showed significant differences between the clusters only in the relation to the average daily working hours. The majority of people who were working on average more than $10 \mathrm{~h}$ per day were in WHIgroup (see Table 3). The characteristics of people from

Table 5. Significance of differences in age and tenure between clusters (Dunn and Kruskal-Wallis tests results) in study groups

\begin{tabular}{lcccccc}
\hline \multirow{2}{*}{ Variable } & \multicolumn{5}{c}{ Dunn test } & \\
\cline { 2 - 5 } & $\begin{array}{c}\text { HWI+ } \\
\text { group }\end{array}$ & $\begin{array}{c}\text { WHI- } \\
\text { group }\end{array}$ & $\begin{array}{c}\text { No } \\
\text { Interaction } \\
\text { group }\end{array}$ & $\begin{array}{c}\text { Mutual } \\
\text { Positive } \\
\text { group }\end{array}$ & $\begin{array}{c}\text { WHI+ } \\
\text { group }\end{array}$ & Kruskal-Wallis test \\
\hline Age & - & 0.290 & -0.654 & -1.984 & -1.043 & $\mathrm{H}(4,533)=6.856$ \\
HWI+ group & -0.290 & - & -0.908 & -2.128 & -1.252 & \\
WHI- group & 0.654 & 0.908 & - & -1.518 & -0.494 & \\
No Interaction group & 1.984 & 2.128 & 1.518 & - & 0.951 & \\
Mutual Positive group & 1.043 & 1.252 & 0.494 & -0.951 & - & $\mathrm{H}(4,533)=6.816$ \\
WHI+ group & - & & & & & \\
Overall tenure & -1.017 & - & -1.552 & -2.504 & -1.646 & \\
HWI+ group & 0.512 & 1.552 & - & -1.308 & -0.278 & \\
WHI- group & 1.665 & 2.504 & 1.308 & - & 0.947 & \\
No Interaction group & 0.715 & 1.646 & 0.278 & -0.947 & - & \\
Mutual Positive group & & & & & & \\
WHI+ group & & & & & & \\
Tenure at main place of & - & 2.118 & 0.341 & -1.469 & -0.296 & \\
employment & -2.118 & - & -1.936 & $-3.338^{*}$ & -2.318 & \\
HWI+ group & -0.341 & 1.936 & - & -1.866 & -0.641 & \\
WHI- group & 1.469 & $3.338^{*}$ & 1.866 & - & 1.143 & \\
No Interaction group & 0.296 & 2.318 & 0.641 & -1.143 & - & \\
Mutual Positive group & & & & & & \\
WHI+ group & & & & & & \\
\hline
\end{tabular}

$* \mathrm{p}<0.05$.

Abbreviations as in Figure 1. 
Table 6. Characteristics of the part of WHI- group, working on average $>10 \mathrm{~h}$ per day $(\mathrm{N}=19)$

\begin{tabular}{|c|c|c|}
\hline Variable & $\begin{array}{c}\text { Respondents } \\
(\mathrm{N}=19) \\
{[\mathrm{n}(\%)]}\end{array}$ & $\begin{array}{c}\text { Significant differences } \\
\text { between groups } \\
\left(\mathrm{Chi}^{2}\right) \\
\end{array}$ \\
\hline Gender & & 1 vs. 2 \\
\hline men & $14(73.7)$ & \\
\hline women & $5(26.3)$ & \\
\hline Family situation & & 1 vs. 4,2 vs. 4 \\
\hline people living alone & $4(21.1)$ & \\
\hline $\begin{array}{l}\text { people in relationships with dependents (children, other } \\
\text { family members) }\end{array}$ & $10(52.6)$ & \\
\hline $\begin{array}{l}\text { people living in relationship and not declaring to have } \\
\text { children or dependents }\end{array}$ & $4(21.1)$ & \\
\hline people living with parents & $1(5.3)$ & \\
\hline Shift work & & 1 vs. 2 \\
\hline no & $9(47.4)$ & \\
\hline yes & $10(52.6)$ & \\
\hline Employers & & n.s. \\
\hline 1 & $14(73.7)$ & \\
\hline at least 1 or/and self-employment/casual job & $5(26.3)$ & \\
\hline Income & & $\begin{array}{l}1 \text { vs. } 2,1 \text { vs. } 3,1 \text { vs. } 4,1 \text { vs. } 5 \text {, } \\
2 \text { vs. } 3,2 \text { vs. } 4,2 \text { vs. } 5\end{array}$ \\
\hline not sufficient for basic needs & $1(5.3)$ & \\
\hline sufficient only for basic needs & $2(10.5)$ & \\
\hline $\begin{array}{l}\text { sufficient for meeting current needs without having to worry } \\
\text { whether it will be enough until the end of the month }\end{array}$ & $9(47.4)$ & \\
\hline allowing for savings on unplanned expenses in the future & $4(21.1)$ & \\
\hline $\begin{array}{l}\text { high enough that I can live without major sacrifices and put } \\
\text { off for the future }\end{array}$ & $3(15.8)$ & \\
\hline
\end{tabular}

n.s. - not statistically significant.

the WHI- group working more than $10 \mathrm{~h}$ is summarized in Table 6.

Taking socio-demographic characteristics into account, the group of people who experienced WHI- most often and have been working more than $10 \mathrm{~h}$ a day was represented mostly by men, then, to a similar extent by singles, people in relationships with children/dependents and not declaring to have any dependents. As regards income, in this group most of people had income sufficient for meeting current needs without having to worry, or higher. They also worked for 1 employer. People who were experiencing mainly WHI-, to almost the same extent were working in regular hours and in shifts (Table 6).

\section{DISCUSSION}

The results confirmed the validity of the approach proposed by Demerouti and Geurts [26] - we observed various configurations of positive and negative work-home/ home-work interaction and significant differences in level 
of burnout between clusters characterized by different quality of work-home interaction. These results support our 1st 2 hypotheses - H1 and H2. We did not exactly replicate the previous results. We managed to extract 5 clusters, but only 3 of them were similar to the clusters distinguished by the authors mentioned above. These clusters involved people experiencing mainly positive influence of work to home; experiencing positive influence of home to work and people not experiencing any specific interaction. The results may reflect cultural differences between groups expressing, inter alia, the different attitudes towards work and family life, and different values attributed by people to managing roles associated with these areas. The similarities to results of Demerouti and Geurts [26] became apparent in the frequencies of comparable clusters - the largest group was of those with No Interaction $(29 \%)$, then HWI+ (21\%) and WHI+ (18\%). Taking people who experienced any interaction together, they were in a definite majority ( $71 \%$ of the sample). We also did not extract Negative Home-Work Interaction cluster. These results may be explained by a Boundary Theory [42] and integration-segmentation continuum $[43,44]$. It assumes that everyone sets a boundary between occupational and private sphere of life characterized by the 2 features - flexibility and permeability [45]. They constitute a dispositional tendency to experience work-family spillover [46]. Our result shows that the majority of our study group experience rather integration than segmentation. We propose 3 possible explanations. Permeability of boundaries between work and home may be asymmetric and more solid for private life - in other words, in our sample, people did not allow private matters to interfere negatively with their occupational life.

As the impact and the direction of the interaction may depend on the domain that is more important for the individual [47], we assumed that for the majority of our sample, the occupational life was more important. Therefore, we concluded that our respondents protected their work life from the negative influence of the private sphere. This hypothesis, however, demands further studies, which would take into account the role of values in perception of work-home interactions. An optimistic hypothetical explanation of the lack of negative home-work interaction cluster is that there were no significant negative matters that could be transferred to occupational life and our sample consisted of people living satisfactory family life.

Considering the valence of the interaction, regardless of the direction, $55 \%$ of our sample experienced positive interaction and only $16 \%$ of the respondents became a part of the group experiencing negative work-home interaction. We obtained a partial agreement with the results of Cho et al. [46] who suggested that permeability between spheres was stronger for work and for negative events.

The results allow us to arrange the interactions from most to least favorable, indicating that the experience of positive work-home and home-work interactions with the greatest frequency prevents from burnout. In the 2 nd place - the configuration of no certain interaction. The most unfavorable configuration was when it was the negative impact of work on private matters that was experienced most often. The positive quality of work-home relationship helps to cope with the job requirements, allows for better regeneration after work, and thereby, it helps to recover after work and reduce tensions. The negative work-home interaction hinders the possibility to regenerate effectively and causes the accumulation of tensions. People who showed the lowest emotional exhaustion and cynicism and the strongest sense of professional efficacy experienced positive work-home interaction or mutual positive interactions most frequently. People with positive home-work interaction also reported high professional efficacy. Thus, we have confirmed hypotheses $\mathrm{H} 3$ and $\mathrm{H} 4$.

Lack of work-home interaction is not completely neutral - even if the results of No Interaction group were average as regards Emotional Exhaustion and Cynicism, at the same time the group also obtained average 
Professional Efficacy. Thus, the lack of special burden of emotional exhaustion and cynicism does not automatically make people feel more professionally efficient - it proves that although scores in Emotional Exhaustion and Cynicism scales highly correlated with each other $\left(\varrho=0.668^{* *}\right)$, they correlated with Professional Efficacy weaker $\left(\varrho=-0.329^{* *}\right.$ and $\varrho=-0.459^{* *}$, respectively). Demerouti and Geurts [26] suggest that people from this group may use a segmentation strategy to reconcile their work and home spheres.

Our results suggest that segmentation is not an effective strategy - putting the rigid boundaries between professional and private spheres may prevent the positive homework spillover that can be a buffer or a remedy against stress or burnout. The profile of the group HWI+ (low rates of Emotional Exhaustion, and high sense of Professional Efficacy) supports this assumption. But the moderate score in Cynicism scale in this group is worth attention. In our attempt to explain the result, we assume that moderate cynicism can be adaptive, as far as work-life balance issue is taken into account. This kind of cynicism may be understood as an attitudinal distance to workrelated issues (attitude between unhealthy preoccupation and callousness) which may help not to be dominated by occupational duties and problems. On the one hand, as the people from HWI+ group were moderately cynical, probably they were not strongly satisfied with their work but, on the other - they led satisfactory family life. The attitude of emotional distance and not being too involved in work prevent them from negative work-home interaction. As a result, the positive home-work interaction could be the dominant one.

Comparing our results with the study by Demerouti and Geurts [26], we can see that in both studies, there were no significant differences in proportion of men and women in clusters; thus, our hypothesis that women experience positive work-home/home-work interaction less often than men (H5) has not been confirmed. The tenure at the main place of employment and the average number of working hours per day were the only 2 socio-demographic variables which differentiated the quality of work-home interaction in our sample. We observed that people for whom the mutual positive interaction were the most common had the longest tenure at the main place of employment (over 12 years). It can be explained that the length of tenure is associated with the better person-organization fit, and hence, with familiarity with the workplace, an acquisition of habits, customs, a sense of stability that helps to elaborate ways to reconcile and harmonize private and occupational spheres of life.

People who experienced the negative work-home interaction most often were the most exhausted emotionally and cynical. They also had the lowest sense of professional efficacy. This group was mainly represented by people who declared that they worked on average more than $10 \mathrm{~h}$ per day. Thus, we have confirmed our next hypothesis (H6) stating that people working more hours per day are more likely to experience negative work-home/home-work interactions and burnout than those working less. This result is in accordance with the results of Barnett, Gareis and Brennan [48], Keene and Quadagno [49] and Dyrbye et al. [10] who also indicated that the number of working hours was the significant predictor of burnout. Milkie and Peltola [50] discovered gender differences in this term - among the others, longer working hours were the main cause of imbalance only for men, while for women these were the unfairness in sharing housework, marital unhappiness and tradeoffs made at work for family and at home for work.

Contrary to our assumption (H7), the number of employees was not related to the quality of experienced workhome/home-work interaction.

The amounts of respondents working regular hours and these working shifts were similar, so we cannot say that the work pattern itself contributes to the negative workhome interaction, thus the hypothesis $\mathrm{H} 8$ also has not been confirmed. 
Analysis showed that the group of particular vulnerability to the adverse health consequences - people experiencing negative work-home interaction and working more than $10 \mathrm{~h}$ per day were mostly men, people in relationships and having dependents (children, other family members) and people with average income. They were employees of a single employer. Unfortunately, our data made it impossible to indicate the reasons for such an extended work time. This result may reflect the situation of Polish workers, whose excessive work is probably enforced by the personal situation (being a main bread winner, a wide range of responsibilities and professional commitments, excessive work involvement) or economic factors (the crisis, pressure form an employer, the threat of job loss).

\section{CONCLUSIONS}

We conclude that there is a significant relation between the quality of work-home interaction and burnout. Segmentation is not an effective strategy to reconcile life domains - putting rigid boundaries between professional and private spheres may prevent the positive home-work spillover, that can be a buffer or a remedy against stress or burnout. We consider cluster analysis the appropriate method in work-family balance research.

\section{Limitations}

The main limitation of the study is its cross sectional nature, which does not allow to determine that particular work-home interaction prevents respondents from burnout or that the level of burnout influences the quality of their work-home interaction. We could compare the variables selected for the presented model with the model article only to some extent.

We did not explain which factors affected the configuration of work-family interaction. It was beyond the scope of the article and remains a recommendation for further research. Cho et al. [46] suggest that there is a dispositional tendency to link all 4 constructs. In other words, people have a tendency to experience a specific interaction and some of them are predisposed to experience spillover. This phenomenon can be one of the key predictors of the quality of work-home interaction, as well as another possible predictor - negative affectivity. The covering of this issue could be a matter of future research, because the perspectives on this field are wide and there are many hypotheses that can be tested.

\section{Recommendation for future research}

One of the current challenges in this area of research is the expansion of the new forms of families - monoparental families, childless partnerships, informal relationships, co-habitation, same-sex partnerships, families with the members of different culture traditions, etc. The development of work-life theory should take them into account [51]. The context of the global crisis must be also included into new research as for many people it made functioning in more and more demanding occupational and private sphere difficult and less satisfying. Studies in which work environment would be diagnosed and recognized as an independent variable and the work-home interaction as a mediator of burnout should be also conducted.

It should also be noted that work-home interaction is not a personal matter for people living in relationships. A research on American surgeons suggest that the price women pay in case of conflict between their own and their partner's/spouse's careers is higher than among men. The authors have demonstrated that they sacrifice their careers for the good of their partners' careers more often [10]. We suggest that the phenomena of conflict or synergy of work-home interactions experienced by couples has a potential as regards its cognitive value and should be the topic of future research [10]. By synergy versus conflict of interactions we understand the process or effect of mutual reconciliation of duties made by partners which 
can be beneficial for both parties or include excessive load in one of the parties.

The issue of the fit between work and private life could be also an interesting area for further research. Studies on this topic have already been launched by Voydanoff [52]. Such research would enrich our understanding of how people cope with the challenges of meeting demands of their works and their private lives.

Given that the individual predisposition to experience spillover [46] seems to be easier to change than objective work conditions or family situation, from a cognitive point of view, it would be interesting to study the effect of intervention aimed at optimizing/modeling this disposition towards lower or higher permeability.

In further studies a similar analysis could be extended to different occupational groups or individual variables, such as the preference of segmentation between work and home, values, type of work commitment (from enthusiasm to workaholism), etc. In our opinion, a further step enabling in-depth analysis would create a single, continuous variable as an indicator of the quality of work-home interaction. The range of available data mining methods, and the ability to observe the nuances of this phenomenon would certainly become wider. Definitive unraveling complex relationships between these 2 phenomena would allow for development of more effective preventive strategies which may be implemented at macro- and micro-level. This would allow to take a step forward towards the society of people who are fulfilled in various spheres of life, for the benefit of themselves, employers and community they live in.

\section{REFERENCES}

1. Edwards JR, Rothbard NP. Mechanisms linking work and family: Clarifying the relationship between work and family constructs. Acad Manage Rev. 2000;25(1):178-99.

2. Geurts S, Taris T, Kompier M, Dikkers J, van Hooff M, Kinnunen U. Work-home interaction from a work psychological perspective: Development and validation of a new questionnaire, the SWING. Work Stress. 2005;19(4):319-39, http://dx.doi.org/10.1080/02678370500410208.

3. Langballe EM, Innstrand ST, Aasland OG, Falkum E. The predictive value of individual factors, work-related factors, and work-home interaction on burnout in female and male physicians: A longitudinal study. Stress Health. 2011;27(1):73-87, http://dx.doi.org/10.1002/ smi.1321.

4. Lingard H, Francis V. Does a supportive work environment moderate the relationship between work-family conflict and burnout among construction professionals? Constr Manage Econ. 2006;24(2):185-96, http://dx.doi. org/10.1080/14697010500226913.

5. Proost K, de Witte H, de Witte K, Evers G. Burnout among nurses: Extending the Job Demand-Control-Support model with work-home interference. Psychol Belg. 2004;44(4): 269-90, http://dx.doi.org/10.5334/pb-44-4-269.

6. Fiksenbaum L, Koyuncu M, Burke RJ. Virtues, work experiences and psychological well-being among managerial women in a Turkish bank. Equality Diversity Inclusion Int J. 2010;29(2):199-212, http://dx.doi. org/10.1108/02610151011024501.

7. Maslach C, Schaufeli WB, Leiter MP. Job burnout. Ann Rev Psychol. 2001;52(1):397-422, http://dx.doi.org/10.1146/ annurev.psych.52.1.397.

8. Salanova M, Llorens S. Current state of research on burnout and future challenges. Papeles Psicól. 2008;29(1):59-67.

9. Maslach C. Burnout: The cost of caring. New York: PrenticeHall; 1982.

10. Dyrbye LN, Shanafelt TD, Balch CM, Satele D, Sloan J, Freischlag J. Relationship between work-home conflicts and burnout among American surgeons: A comparison by sex. Arch Surg. 2011;146(2):211, http://dx.doi.org/10.1001/archsurg.2010.310.

11. Keeton K, Fenner DE, Johnson TRB, Hayward RA. Predictors of physician career satisfaction, work-life balance, and burnout. Obst Gynecol. 2007;109(4):949, http://x.doi. org/10.1097/01.AOG.0000258299.45979.37. 
12. Shanafelt TD, Boone S, Tan L, Dyrbye LN, Sotile W, Satele D, et al. Burnout and satisfaction with work-life balance among US physicians relative to the general US population. Arch Intern Med. 2012;172(18):1377-85, http:// dx.doi.org/10.1001/archinternmed.2012.3199.

13. Brauchli R, Bauer GF, Hämmig O. Relationship between time-based work-life conflict and burnout: A cross-sectional study among employees in four large Swiss enterprises. Swiss J Psychol. 2011;70(3):165, http://dx.doi.org/10.1024/ 1421-0185/a000052.

14. Montgomery AJ, Peeters MCW, Schaufeli WB, Den Ouden M. Work-home interference among newspaper managers: Its relationship with burnout and engagement. Anxiety Stress Coping. 2003;16(2):195-211.

15. Hobfoll SE. The influence of culture, community, and the nested-self in the stress process: Advancing conservation of resources theory. Appl Psychol. 2001;50(3):337-421, http:// dx.doi.org/10.1111/1464-0597.00062.

16. Johnson JV, Hall EM. Job strain, work place social support, and cardiovascular disease: A cross-sectional study of a random sample of the Swedish working population. Am J Public Health. 1988;78(10):1336-42, http://dx.doi.org/10.2105/ AJPH.78.10.1336.

17. Bakker AB, Demerouti E. The job demands-resources model: State of the art. J Manag Psychol. 2007;22(3): 309-28, http://dx.doi.org/10.1108/02683940710733115.

18. Barnett RC, Hyde JS. Women, men, work, and family: An expansionist theory. Am Psychol. 2001;56(10):781-96, http://dx.doi.org/10.1037/0003-066X.56.10.781.

19. Grzywacz JG. Work-family spillover and health during midlife: Is managing conflict everything? Am J Health Promot. 2000;14(4):236-43, http://dx.doi.org/10.4278/08901171-14.4.236.

20. Grzywacz JG, Bass BL. Work, family, and mental health: Testing different models of work family fit. J Marriage Fam. 2003;65(1): 248-61, http://dx.doi.org/10.1111/j.1741-3737.2003.00248.x.

21. Geurts SAE, Kompier MAJ, Roxburgh S, Houtman ILD. Does work-home interference mediate the relationship between workload and well-being? J Vocat Behav. 2003;63(3):532-59, http://dx.doi.org/10.1016/S00018791(02)00025-8.

22. Peeters MCW, Montgomery AJ, Bakker AB, Schaufeli WB. Balancing work and home: How job and home demands are related to burnout. Int J Stress Manage. 2005;12(1):43-61, http://dx.doi.org/10.1037/1072-5245.12.1.43.

23. Carlson D, Ferguson M, Hunter E, Whitten D. Abusive supervision and work-family conflict: The path through emotional labor and burnout. Leadership Quart. 2012;23 (5):849-59, http://dx.doi.org/10.1016/j.leaqua.2012.05.003.

24. Judge TA, Colquitt JA. Organizational justice and stress: The mediating role of work-family conflict. J Appl Psychol. 2004;89(3):395-404, http://dx.doi.org/10.1037/00219010.89.3.395.

25. Mostert K, Peeters M, Rost I. Work-home interference and the relationship with job characteristics and well-being: A South African study among employees in the construction industry. Stress Health. 2011;27(3):e238-51, http:// dx.doi.org/10.1002/smi.1374.

26. Demerouti E, Geurts S. Towards a typology of work-home interaction. Community Work Fam. 2004;7(3):285-309, http://dx.doi.org/10.1080/1366880042000295727.

27. Hall GB, Dollard MF, Tuckey MR, Winefield AH, Thompson BM. Job demands, work-family conflict, and emotional exhaustion in police officers: A longitudinal test of competing theories. J Occup Organ Psychol. 2010;83(1):237-50, http://dx.doi.org/10.1348/096317908X401723.

28. Innstrand ST, Langballe EM, Espnes GA, Falkum E, Gjerl O. Positive and negative work-family interaction and burnout: A longitudinal study of reciprocal relations. Work Stress. 2008;22(1):1-15, http://dx.doi. org/10.1080/02678370801975842.

29. Demerouti E, Bakker AB, Bulters AJ. The loss spiral of work pressure, work-home interference and exhaustion: Reciprocal relations in a three-wave study. J Vocat Behav. 2004;64(1):131-49, http://dx.doi.org/10.1016/S0001-87 91(03)00030-7. 
30. Montgomery AJ, Panagopolou E, Benos A. Work-family interference as a mediator between job demands and job burnout among doctors. Stress Health. 2006;22(3): 203-12, http://dx.doi.org/10.1002/smi.1104.

31. Bacik I, Drew E. Struggling with juggling: Gender and work/life balance in the legal professions. Women Stud Int Forum. 2006;29(2):136-46, http://dx.doi.org/10.1016/ j.wsif.2006.03.006.

32. Emslie C, Hunt K. 'Live to Work' or 'Work to Live'? A qualitative study of gender and work-life balance among men and women in mid-life. Gender Work Organ. 2009;16(1):151-72, http://dx.doi.org/10.1111/j.14680432.2008.00434.x.

33. Kollinger-Santer I, Fischlmayr IC. Work life balance up in the air - Does gender make a difference between female and male international business travelers? Z Personalforsch. 2013;27(3):195-223, http://dx.doi.org/10.1688/18620000_ZfP_2013_03_Kollinger-Santer.

34. Gander P, Briar C, Garden A, Purnell H, Woodward A. A gender-based analysis of work patterns, fatigue, and work/ life balance among physicians in postgraduate training. Acad Med. 2010;85(9):1526-36, http://dx.doi.org/10.1097/ ACM.0b013e3181eabd06.

35. Byron K. A meta-analytic review of work-family conflict and its antecedents. J Vocat Behav. 2005;67(2):169-98, http:// dx.doi.org/10.1016/j.jvb.2004.08.009.

36. Eby LT, Casper WJ, Lockwood A, Bordeaux C, Brinley A. Work and family research in IO/OB: Content analysis and review of the literature (1980-2002). J Vocat Behav. 2005;66(1):124-97, http://dx.doi.org/10.1016/ j.jvb.2003.11.003.

37. Steinmetz H, Frese M, Schmidt P. A longitudinal panel study on antecedents and outcomes of work-home interference. J Vocat Behav. 2008;73(2):231-41, http://dx.doi. org/10.1016/j.jvb.2008.05.002.

38. Mościcka-Teske A, Merecz-Kot D. [Polish Adaptation of SWING Questionnaire (Survey Work-Home Interaction Nijmengen)]. Med Pr. 2012;63(3):355-69. Polish.
39. Schaufeli WB, Leiter MP, Maslach C, Jackson SE. The MBI-General Survey. In: Maslach C, Jackson SE, Leiter MP, editors. Maslach Burnout Inventory, Manual. 3 ed. Palo Alto, CA: Consulting Psychologists Press; 1996. p. 19-26.

40. Mojsa J, Dyląg A, Pałczyńska E. Psychometric properties of a Polish version of the Maslach Burnout Inventory-General Survey (MBI-GS) in a group of Information and Communication Technology (ICT) specialists. Ergon Int J Ergon Hum Fact. 2006;28(4):351-61.

41. AZB. AZB analysis \& software. Dunn's Test (post-hoc Dunn's test analysis software), version 7.01 [cited 2014 March 7]. Available from: http://www.azb.com.pl.

42. Nippert-Eng C. Calendars and keys: The classification of "home" and "work". Sociol Forum. 1996;11(3):563-82, http://dx.doi.org/10.1007/BF02408393.

43. Ashforth BE, Kreiner GE, Fugate M. All in a day's work: Boundaries and micro role transitions. Acad Manage Rev. 2000:472-91.

44. Rothbard NP, Phillips KW, Dumas TL. Managing multiple roles: Work-family policies and individuals' desires for segmentation. Org Science. 2005;16(3):243-58, http://dx.doi. org/10.1287/orsc.1050.0124.

45. Hall DT, Richter J. Balancing work life and home life: What can organizations do to help? Acad Manag Exec. 1988; 2(3):213-23, http://dx.doi.org/10.5465/AME.1988.4277258.

46. Cho E, Tay L, Allen TD, Stark S. Identification of a dispositional tendency to experience work-family spillover. J Vocat Behav. 2013;82(3):188-98, http://dx.doi.org/10.1016/ j.jvb.2013.01.006.

47. Frone MR. Work-family balance. In: Quick JC, Tetric LE, editors. Handbook of occupational health psychology. Washington, DC: American Psychological Association; 2003. p. 143-62, http://dx.doi.org/10.1037/10474-007.

48. Barnett RC, Gareis KC, Brennan RT. Fit as a mediator of the relationship between work hours and burnout. J Occup Health Psych. 1999;4(4):307, http://dx.doi.org/10.1037/10768998.4.4.307. 
49. Keene JR, Quadagno J. Predictors of perceived workfamily balance: Gender difference or gender similarity? Sociol Perspect. 2004;47(1):1-23, http://dx.doi.org/10.1525/ sop.2004.47.1.1.

50. Milkie MA, Peltola P. Playing all the roles: Gender and the work-family balancing act. J Marriage Fam. 1999;61(2): 476-90, http://dx.doi.org/10.2307/353763.

51. Özbilgin MF, Beauregard TA, Tatli A, Bell MP. Work-life, diversity and intersectionality: A critical review and research agenda. Int J Manag Rev. 2011;13(2):177-98, http://dx.doi. org/10.1111/j.1468-2370.2010.00291.x.

52. Voydanoff P. Toward a conceptualization of perceived work-family fit and balance: A demands and resources approach. J Marriage Fam. 2005;67(4):822-36, http://dx. doi.org/10.1111/j.1741-3737.2005.00178.x.

This work is available in Open Access model and licensed under a Creative Commons Attribution-NonCommercial 3.0 Poland License - http://creativecommons.org/ licenses/by-nc/3.0/pl/deed.en. 